\title{
WALT WHITMAN, TRINITY CHURCH, AND ANTEBELLUM REPRINT CULTURE
}

\author{
SCOTT T. ZUKOWSKI
}

Chapter XIX of Life and Adventures of Fack Engle: An Autobiography (1852)Walt Whitman's recently rediscovered serialized novel— has been the focal point of virtually all attention given to the novel since its appearance in the Walt Whitman Quarterly Review in 2017. The chapter has been called a "magical moment," a moment that foretells the coming of the Walt Whitman we know from the first edition of Leaves of Grass three years later. ${ }^{1}$ Indeed, there is much in the chapter that strikingly prefigures Leaves of Grass. The chapter details the visit of the novel's protagonist, Jack Engle, to Trinity Churchyard in lower Manhattan. During his walk through the tombstones, Jack reflects on the dead beneath his feet and the living that he can hear on Broadway, just beyond the bounds of the shady, peaceful graveyard. He becomes enraptured in meditation about life, death, history, present, and country, and he even remarks on the "long, rank grass" growing above the graves. Yet, the chapter functions as more than a foreshadowing of the Whitman to come; it provides a glimpse into the influences of Whitman's past as an editor, contributor, and consumer of newspapers.

Though the chapter's prefiguring of motifs and themes from Leaves of Grass has been central to previous readings, perhaps its most fascinating aspect is that it is distinctly unoriginal material, drawn from a decades-old newspaper literature trope that commonly featured a narrator experiencing an extended moment of romantic elevation while visiting Trinity Churchyard. Drawing and building upon an established tradition of graveyard poetry, the trope arose in the late 1820 s, as other periodical texts about Trinity Churchyard simultaneously established the actual location as a site of America's semi-mythologized national origins. The trope continued to develop throughout the Antebellum Period as a unique and popular vehicle, as we will see, for a nation grappling with its past, present, and future, and with unsettled questions of identity.

This essay is organized in three sections, each with its own task. The first section, "Trinity Churchyard in American Culture, 1820-1855," discusses the representation of Trinity Churchyard in the non-literary prose texts of American 
periodicals. In doing so, it locates Trinity Churchyard as a site of increasing local and national cultural importance. The second section, "Hours in Trinity Churchyard," places the trope of Trinity Churchyard in the context of nineteenth-century graveyard poetry. It then analyzes three examples of the trope preceding Fack Engle, including one example authored by Whitman himself, and it identifies common elements of the trope-some that are shared with other graveyard poetry and some that are unique. The third section, "Jack Engle, the American Orphan," offers an analysis of Whitman's serial novel that builds on and draws from these contexts of the trope's established history and meanings.

I'm setting out here to demonstrate two critical concepts. First, during the Antebellum Period, Trinity Churchyard held an important place in American cultural identity, evident in the plethora of newspaper texts from around the country associating it with a semi-mythologized narrative of national origin. Urban graveyards, then, performed important cultural functions that scholarship has overlooked because of its focus on the rural cemetery movement that began in the 1830s. Second, Whitman tapped into the Trinity Churchyard trope as a tool for the exploration and articulation of a unified national identity and a literature for which Americans of the period were searching. My approach grows out of an appreciation for the reprint culture of the nineteenth century, and in no way am I questioning the creativity or literary originality of Walt Whitman. It is instead a study in the sharing of ideas and the open circulation of texts in a period when reprinting and "borrowing" of literary material was common. ${ }^{2}$

\section{Trinity Churchyard in American Culture, 1820-1855}

The Trinity Church of 1852 - when Whitman wrote Fack Engle-was actually the third Trinity Church to be erected on the same land. The first, built in 1697, was destroyed during New York's Great Fire of 1776, in the early days of the British occupation of the city following the Revolutionary War's Battle of Long Island. ${ }^{3}$ In 1790, a new, bigger church opened in its place. This church was demolished in 1839 and, in 1846, replaced by the current edifice, described by a popular 1859 New York guide-book as "the most elegant and cathedral-like of the churches of the city." Jack Engle himself calls Trinity Church "one of the finest pieces of architecture in the New World." Despite changes in the church itself, the graveyard surrounding the church faced little alteration other than the continual addition of new graves. ${ }^{6}$ In fact, while there is scant evidence of serious objection to the destruction of the second church and the construction of the third, there is ample documentation of the personal and cultural invest- 
ment that New Yorkers placed in the preservation and maintenance of Trinity's graveyard.

This investment is observable first in the early 1820 s, when attention to health conditions in the immediate vicinity of Trinity Churchyard spiked. Other than notices of church services, the most frequent mention of Trinity Church in American newspapers during this time was in relation to sanitation concerns. In 1822, for example, Poulson's American Daily Advertiser published a report from the New York Board of Health stating that multiple cases of yellow fever had surfaced in the residences surrounding Trinity Churchyard. It suggested that, "in the evenings especially, the exhalations [from the graves] are such as, perhaps, to be dangerous to the health of the citizens in its immediate neighborhood." A Another newspaper concurred that the outbreak was linked to the graveyard-specifically the opening of tombs for new burials: "On the opening of every grave a very disagreeable, if not pernicious, effluvia arises therefrom; that during the heavy rains which we had for some time past, a great quantity of earth was washed over the stone wall into Lumber-st." resulting in "so noisome a stench that the inhabitants of that street were under the necessity of closing their doors and windows." 8 The author's recommendations were to cover the yard in a layer of lime, to stop burials there altogether, and to pave over the graveyard with the tombstones themselves. The first of these suggestions was pursued, but it was later reported that "the stench arising from thence was so excessive as to cause several of [the lime-laying] laborers to cascade freely." 9 Despite several such considerations and suggestions of sanitary improvement, substantial changes to the churchyard were strongly opposed in New York's newspapers. This is not to say that the city's population was in unanimous agreement about Trinity Churchyard's significant symbolism: that there were so many publications advocating for the preservation of the site suggests that there was also considerable sentiment opposing such preservation and that the graveyard was a site of contestation during the 1820 s and early $1830 \mathrm{~s}$. Yet, it is significant that, even in an era when the site was thought to be a health risk, a sense of its cultural sanctity and untouchability pervaded.

In fact, it is in New Yorkers' reactions to proposed alterations of Trinity Churchyard that we can observe the growing association between the site and an emerging national identity based on a patriotic, semi-mythical past. One writer, self-identified as "A Member of Trinity Church," argued against the proposed cessation of burials by reminding his reader that the yard had been used for interment "since the foundation of the city," implying a sacred relationship between the churchyard and New York's civic origins. The words of another writer reveal 
the public outrage at the proposal to extend Albany Street through the churchyard: "The indignation, great and-we are glad to say to the honor of the citygrowing as it is, at the violation so wantonly contemplated of this ancient burial place ...." Reports of public "indignation" (appearing mostly in New York papers but also in papers as far as Alabama ${ }^{11}$ demonstrate the importance of Trinity Churchyard for nineteenth-century New Yorkers, and they suggest that threats to the site increased the churchyard's status as a symbol of New York's history and cultural identity by bringing New Yorkers together in defense of its preservation. Another writer who called himself "Knickerbocker" and referred to New York City as "this goodly city of New Amsterdam," railed against the same Albany Street proposal. ${ }^{12}$ His Dutch phrasing connects the churchyard with New York's Dutch origins, which, a half-century after the Revolution, provided a civic myth for writers like Washington Irving to explore as a route toward a distinctly New Yorkish cultural ancestry and identity. After describing the dilapidated tomb of War of 1812 hero Captain James Lawrence, one writer in a South Carolina paper urged against repairing it, suggesting that the "city contains nothing half so noble or half so interesting." 13 The cultural value of the American icon's burial site and the nostalgia it evoked were compounded by its visible age and its seemingly ancient condition. Trinity Churchyard was not just a place to see local graves; it was a place that connoted the ancient and "noble" history that nineteenth-century America otherwise lacked, and it was a place to personally engage with the graves of distinguished American forefathers.

In the period between 1825 to 1860, descriptions of certain tombstones in Trinity Churchyard formed a literary staple for newspaper writers concerned with the site, whether they were publishing in New York or beyond. It is significant that the tombs of Captain Lawrence and Alexander Hamilton were among those most frequently referenced. They emblematized ideals of American patriotism, one as a valorous American military martyr and the other as a founding figure in the country's (and city's) semi-mythical past. Arguing against the emerging paradigm of the rural cemetery, an 1833 letter to the editors of a Baltimore newspaper posited that there was a "thrilling interest which may be concentrated around a single church, or church-yard, by the presence there of the relics of a few great men." ${ }^{14}$ After pointing out that Washington and Franklin were buried in private cemeteries, he then linked Trinity with these American forefathers by considering that "Hamilton and Lawrence repose together in Trinity Church yard, New York . ..." He mused that in small, urban graveyards like Trinity, the urban-faring American could be "alone with the Father[s] of our Country." Further, the authors of such pieces, whether from New York, Nantucket, or 
elsewhere, often either linked Hamilton with Washington or made clear that many Revolutionary War dead were interred in the churchyard. ${ }^{15}$ By the early 1850s, newspapers from as far as California and Mississippi and Maine were printing articles about Trinity Church's new monument to fallen Revolutionary War soldiers. ${ }^{16}$ This pattern of linking Trinity Churchyard with national origins appeared in newspaper texts frequently between the 1820s and 1850s.

In fact, while Whitman was editor of the Brooklyn Daily Eagle in 184648, the paper published three articles concerning Lawrence's tomb. The texts are important for two reasons: they indicate Whitman's familiarity with periodical texts on Trinity Churchyard (if not as writer, then at least as editor), and they also provide insight into popular opinions on the cultural value of Trinity Churchyard. The first article stated that Lawrence's monument, which had long been in a state of dilapidation, "remains a ruin:-(And yet it is perhaps as well so. We can never fully see the harmony of a bright bran new tomb-memorial of a

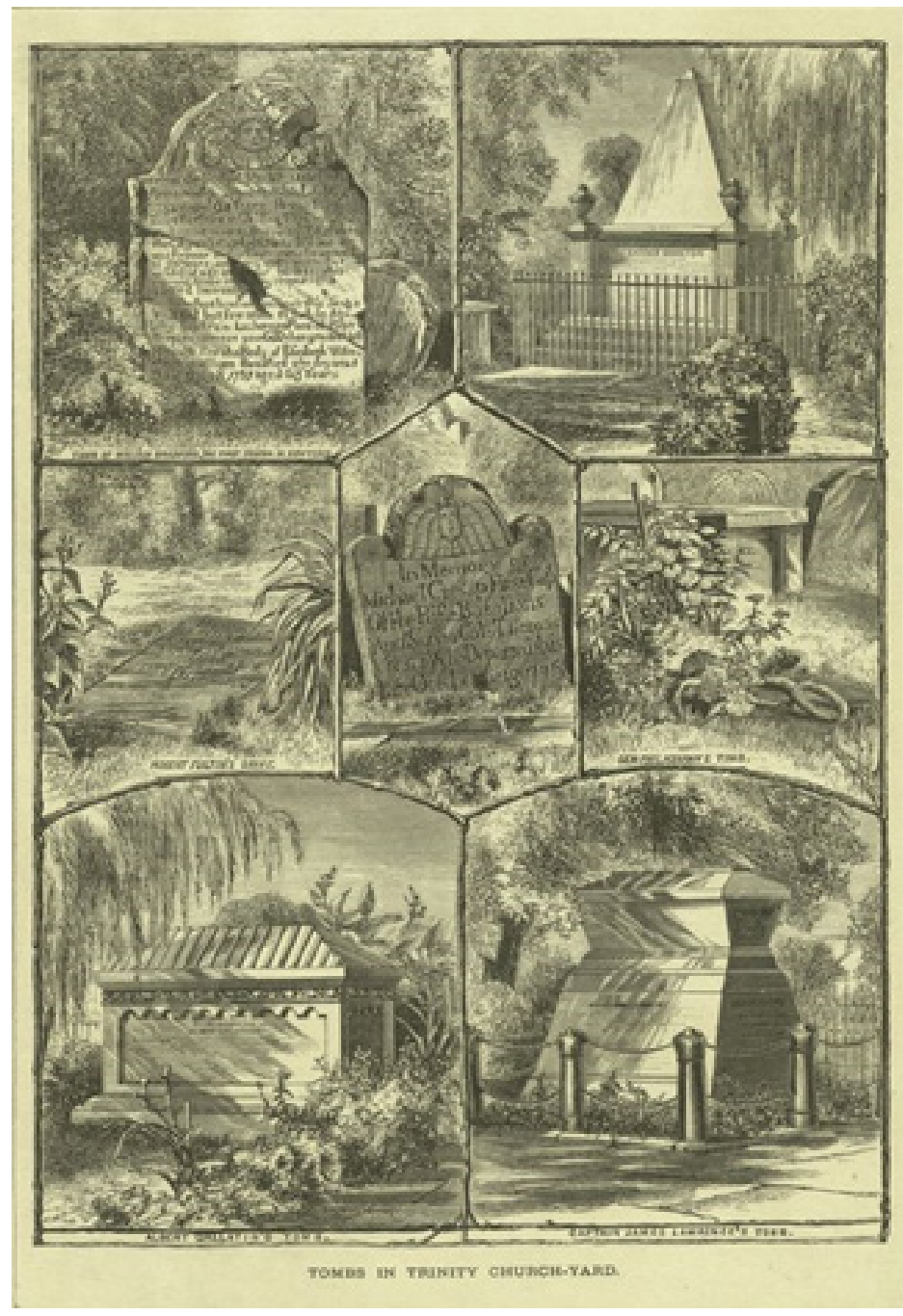

Figure 1: "Tombs in Trinity Church-yard," from The New York Public Library. 
really lamented man.)." ${ }^{\prime 17}$ In other words, the tomb's poor condition contributes to its affective power and to a nostalgic sense of American antiquity as might the ruins of an ancient civilization. ${ }^{18}$ A month later, in the same paper, a longer piece stated that "we confess, for our part, to a kind of horror at any thing that seems like disturbing the ashes, or the mortal resting place, of the departed." 19 It was especially appalling for the author because, as he put it, "there is nothing more excellent than the disposition to honor the names of heroes and brave defenders of the land-founded as it is in that noble passion, love of country." He would go on to tell of his own tearful visit to Lawrence's tomb and provide a transcription of the tomb's inscription. The article reasserts the nationalistic value in Trinity Churchyard, specifically through its visit to the tomb of the War of 1812 hero. Four months later appeared a third article, which provided the new tomb's inscriptions for the reader and included no criticism of the decision to erect the new monument. ${ }^{20}$ Given Whitman's employment at the Daily Eagle at the time, and, given his interest in America's patriotic history and the sites of lower Manhattan, it is plausible that Whitman authored these pieces, or at the very least was likely to have read them as editor. ${ }^{21}$ The texts' conflicting tensions between old and new, between the romanticized past and the modernizing present, between New York's graveyard and America's past, surfaced repeatedly in newspapers throughout the period and, as we will see later, in Whitman's own literary corpus.

The "Member of Trinity Church" quoted earlier-who opposed disruptive changes to the churchyard and anticipated the deepening identification of the location as a site of national memory-also draws our attention to the role that Trinity Churchyard would increasingly play as a muse for reflections on the tension between modernization and reflective reverie centered on mortality. He asks, "is there no good moral effect in the position of cemeteries in the middle of the city, so that some times at least, the career of business or pleasure may be arrested by the memorials of mortality?" For him, the location of the graveyard amid the crowded rush of modern urban life was important for helping New Yorkers to consider the delicate balance between "business or pleasure" and "mortality." Indeed, Trinity Churchyard's lower Manhattan location at the junction of fashionable, decadent Broadway and commercial, capitalistic Wall Street was one of its most enticing and provocative allurements for nineteenth-century New Yorkers. One 1837 Maryland writer described lower Broadway as "the most fashionable promenade in the whole city," filled with "all shapes, and hues, and conditions, and distinctions; all varieties of beauty, [ . . . ] wealth and poverty," including young dandies and exotic "foreign gentlemen 
of great distinction, and superb mustachios." 22 Drivers on Broadway, who were "certainly greater brutes than the animals they control," were remarked to be more like "slayers" than "sleighers." 23 Wall Street, meanwhile, notable for its "magnificence temples of Mammon," was such a symbol of modernity and progress that one writer remarked that he "should not be surprised to see old Trinity itself, laid prostrate to make way for Wall-Street to the Hudson." ${ }^{24}$ It is largely this juxtaposition of traditional and progressive, quiet and noisy, peaceful and chaotic, virtuous and decadent, romantic past and modernizing present, that made Trinity Churchyard a popular literary trope for grappling with questions of identity, cultural roots, shifting values, and changing landscapes as New York and America ushered forward.

These tensions, which I summarily refer to as the tension between reflective reverie and modernity, became more pronounced during the $1830 \mathrm{~s}$ and $40 \mathrm{~s}^{25}$ While modernity in America is sometimes understood as emerging toward the end of the nineteenth century, I follow the lead of Richard Brown, Jürgen Heideking, and Dorothy Ross, who have thoroughly demonstrated American modernity's development in the late eighteenth and early nineteenth centuries. Brown identifies evidence for this in the American system of government, territorial expansion, population growth, technologies of production of transportation, a national marketing network, the rise of mass production, an elaborate postal network, reform movements, and a host of other factors. ${ }^{26}$ Likewise, Heideking identifies an American "pattern of modernity," marked by Enlightenment thought, shaping the Revolution and the early national period alike. ${ }^{27}$ Most recently, Ross has illustrated that modernity - "a stage of history characterized by national state formation, industrialization, and the rise of new ideas of reason, human agency, and historical progress"-is a key feature of the late eighteenth and early nineteenth centuries in America. ${ }^{28}$ It is worth noting that the urban population of the United States increased from 5\% in 1790 to nearly $20 \%$ in 1850, and David Reynolds points out that, between 1820 and 1850, New York City's population increased from less than 125,000 to more than 500,000. ${ }^{29}$ New York witnessed a building boom beginning in the early 1830s, momentarily stymied by the Great Fire of 1835 and the Panic of 1837, only to recommence with even greater ambition by the $1840 \mathrm{~s} .{ }^{30}$ During these years, New York - and particularly Broadway - would become a symbol of the ideology of what Whitman himself called "tear down and build over again," or destroying old or simply out-moded buildings and replacing them with new, more visually appealing ones. ${ }^{31}$ Social change during these years was also significant: temperance and reform movements, the Women's Rights Movement, and 
WWQR Vol. 37 Nos. 3/4 (WINTER/SPRING 2020)

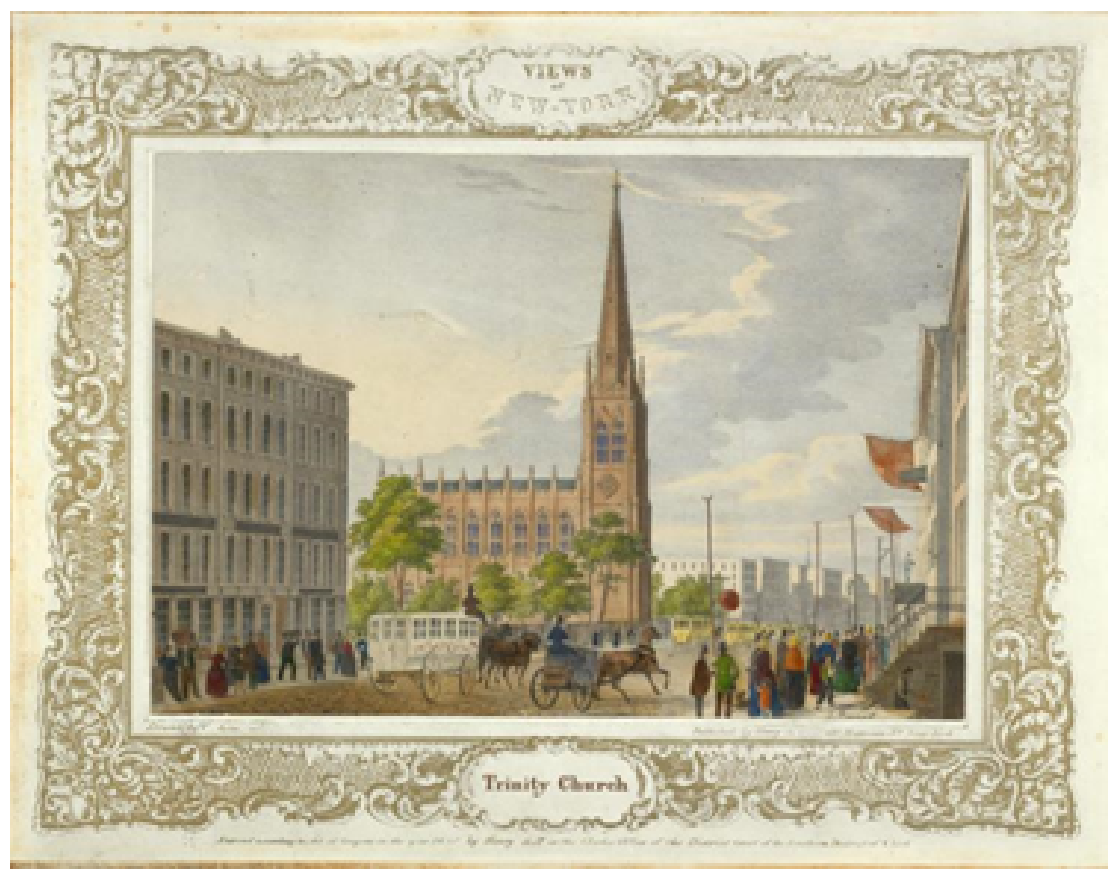

Figure 2 (Left): "Trinity

Church," by C. F. Autenrieth, 1850. Courtesy of NYPL.

Figure 3 (Right):

"Trinity Church, from Wallstreet," by Henry W.

Herrick, 1849. Courtesy of NYPL.

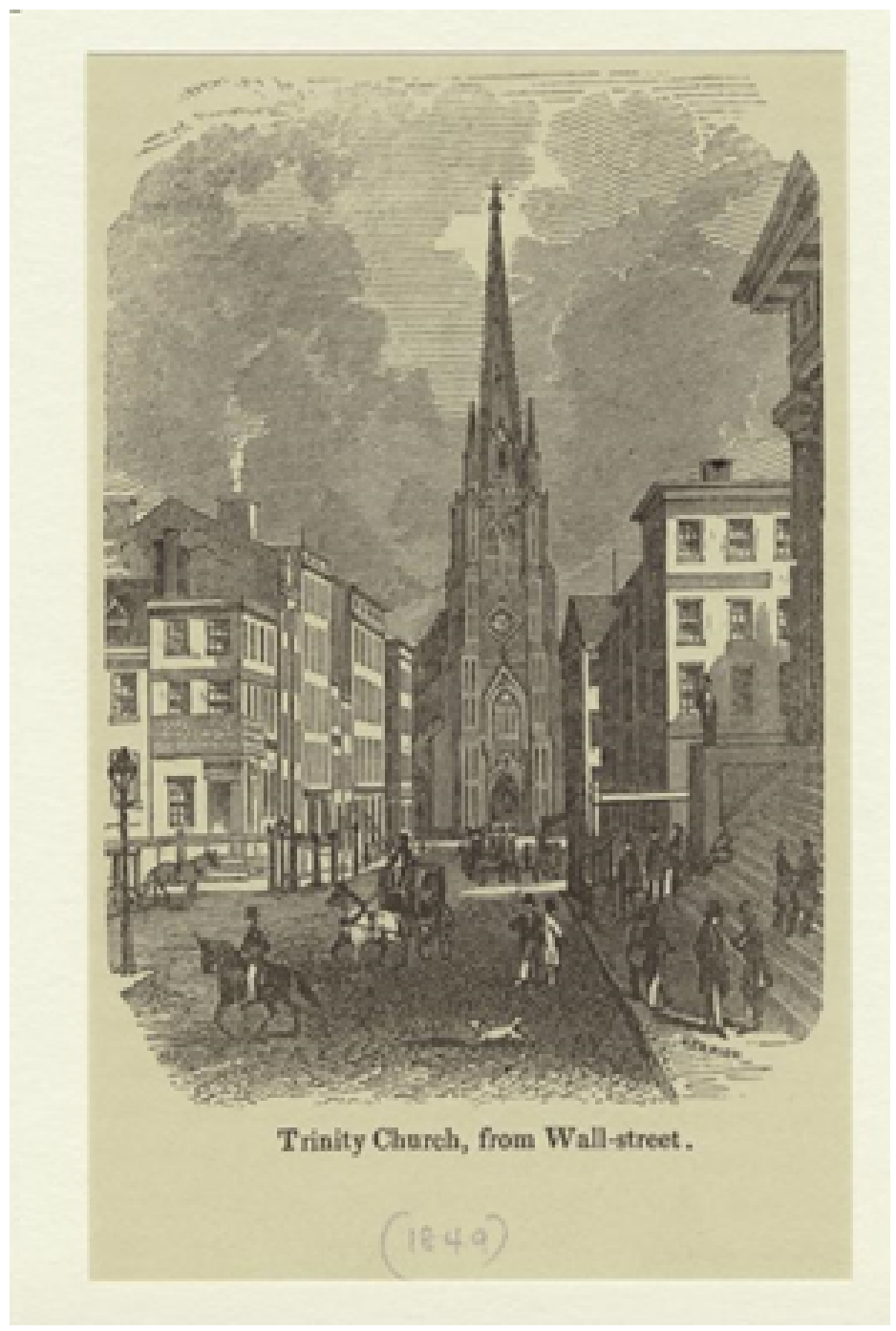




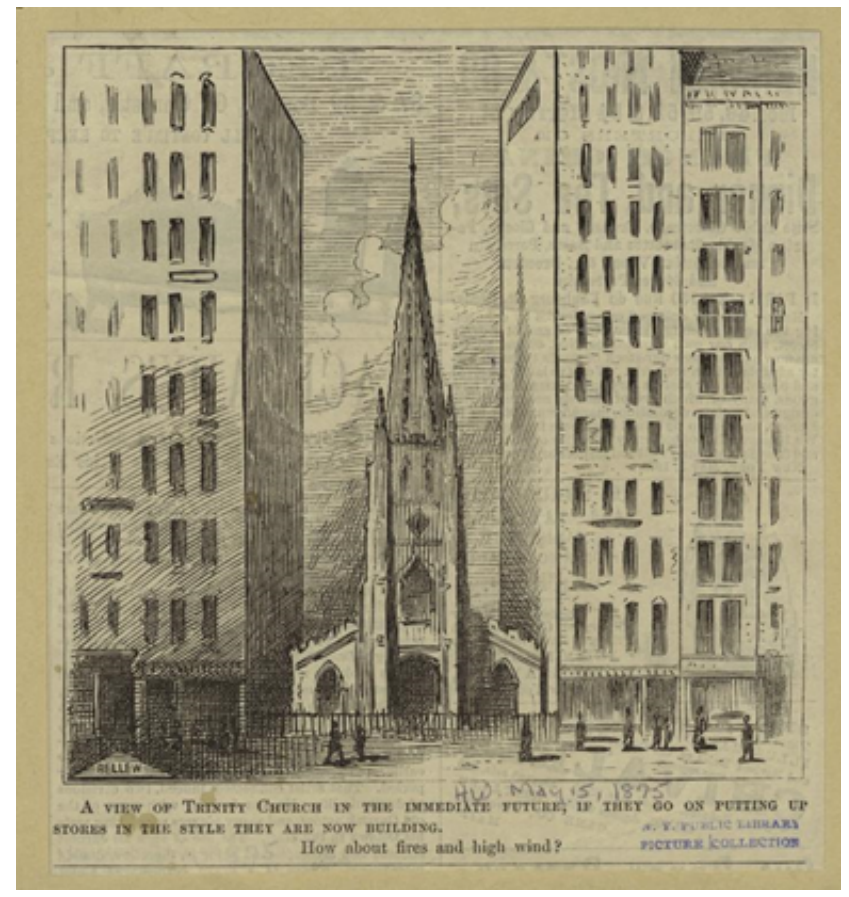

Figure 4 (left): This 1875

image shows that, even later in the nineteenth century,

Trinity Church was a symbolic site of the tensions between the romanticized past and modernity. Courtesy of NYPL.

Figure 5: "Bird's Eye View of Trinity Church, New York," by John Forsyth (1847). This image emphasizes the juxtaposition of Trinity Churchyard's natural elements with the surrounding urban environment. Courtesy of Metropolitan Museum of Art.

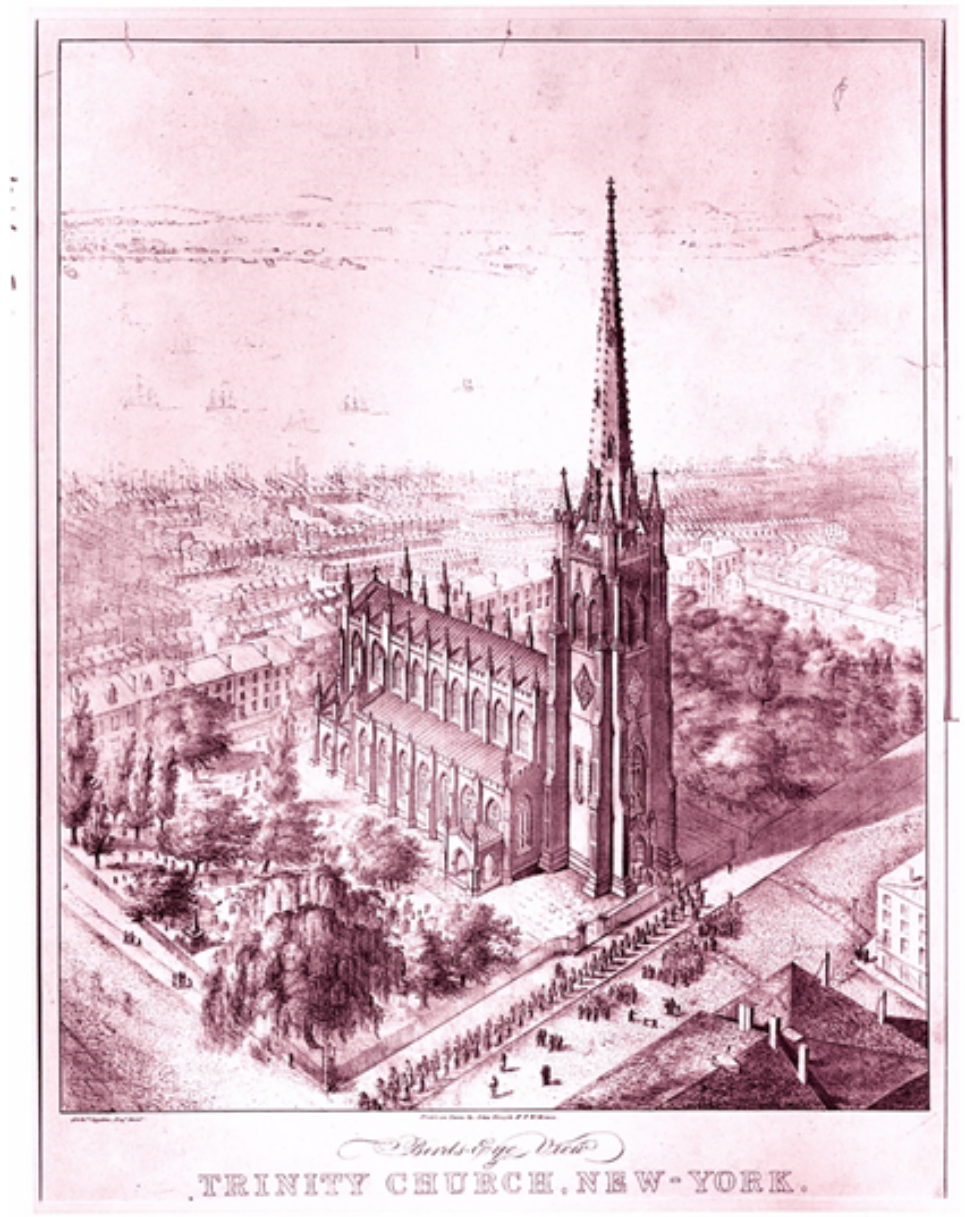


the 1827 emancipation of enslaved people in New York State. One result of all this was a city advancing energetically into a continuously more modern version of itself; the other result was a city fraught with anxiety about its connection to the past.

This anxiety can be traced as it visibly manifested in newspaper texts about Trinity Churchyard throughout the 1830s and 40s. In 1833, reflecting on the proposed Albany Street extension through "the hallowed spot" of Trinity Churchyard, one contributor to the New-York American asserted that "Our Corporation[s] know no God but mammon, and would sarifice [sic] upon his altar every lingering relic of religion their unhallowed avarice has spared." 32 The capitalistic desires of lower Manhattan contrast with the sacred, traditional values represented by the churchyard. "Modern wisdom," the writer continues, "has discovered that the sacred veneration of the grave is but a relic of a barbarous superstition." The proposed disruption of Trinity Churchyard was more than a threat to the preservation of a site of cultural and religious importance; it was the manifestation of an urbanizing culture grappling with technological advancement, with increases in population, wealth, and extravagance, and with the disruption of cultural identity stemming from such change.

In 1852, Mobile's Alabama Planter published an article lamenting that "the bones of a former generation interred in Trinity churchyard . . have been dug up from their graves to clear the ground for the foundations of a row of new dry goods palaces." 33 The writer states that "all people having a proper respect for the dead" had "been shocked by [the] outrage," which, were it not for "an extensive police force . . . around the scene of desecration," might have provoked a "tumult" or "a great riot." More than simply illustrating the public's veneration for the churchyard, the author contrasts the sanctity of the "former generation" with the new, capitalistic "palaces" of trade. In characterizing the stores as "palaces," he frames the intrusion not just as extravagant, but also as something distinctly un-American. Palaces were, after all, a thing of monarchical European societies, not of America.

Anxious negotiations of old and new identities are particularly evident in a poem, "City Lyrics. A Hymn," published in the New York Herald in $1846 .{ }^{34}$ The preeminent Democratic penny press of the Antebellum Period, the Herald was known for both sensationalizing and moralizing, and for its appeal to "a diverse, mass audience, which included [ . . . ] business leaders and sensation seekers," working people and the "intelligent and higher classes of society" on Wall Street. ${ }^{35}$ The appearance of the poem, which is "To be Sung before Desecrating Trinity Graveyard, by an Extension of Pine Street," in the Herald indicates the 
popular presence of Trinity Churchyard in local and larger national culture. The first verse opens: "Away with their dust, / They've slept here too long; / Remove them we must, / For our interest is strong." The speaker satirically sides with those in favor of the extension, arguing to disregard the dead. The "interest," of course, is not just the focused attention of the Pine Street extension supporters; it is the financial benefit and monetary "interest" they will gain through the disruption of the churchyard. Underscoring the extension plan's blatant indifference to virtue, the speaker states that construction must begin at night, "For in the broad daylight / 'Twould look like a sin." He reminds the reader that "Our hearts are all hardened / When gain is let in," and sardonically agrees that "the ground that is holy" should "be bartered for gold." The repeated emphasis on "interest," "gain," and "gold" is not simply a rhetorical attack on the supporters of the extension. Instead, it reflects and perpetuates the tension between the sacred and reveristic values of memory, mortality, and religion, and the modern, capitalistic values of progress, increase, and efficiency.

In 1843, during the construction of the third Trinity Church, author Nathaniel Parker Willis wrote to DC's National Intelligencer "moralizing" (as one reprint phrased it) about the tree leaves in Trinity Churchyard that are "always a week in advance of all others in the city." ${ }^{36}$ He suggests that the early growth is the result of "cadaverous stimulus, and perhaps accelerated particularly, this year, by the heat of the steam-engine, which, with remorseless travestie, perpetually saws stone for the new building over the 'requiescat in pace!" Willis ties technology directly to the natural and spiritual elements found in the yard, drawing attention to the unsettling relationship between reflective reverie and modernity. He laments that the "Poor ghosts" below are disturbed- "robbed" of their tombs" "poetry and respect"-by the "steam-engine and stonecutter's saw . . . a-top of the sod which . . . is expected to 'lie lightly on the dead man's breast!'" Yet he also displays an eager excitement for the new building that will result from the construction: "this exquisitely-conceived piece of architecture . . . is rising with admirable effect, and, when completed, it will doubtless be the first Gothic structure in America."

Willis' attention to the trees at the site suggests the complicated role of urban pastoralism in shaping Trinity Churchyard as a space of reflection. While Desirée Henderson has suggested that there is an inherent "opposition" between urban environments and graveside sentiment, and that cities were "essentially incompatible with sentimental mourning practices," my research shows that the juxtaposition of urban and sentimental was appealing and provocative for many nineteenth-century Americans. ${ }^{37}$ Machor's exploration of the urban pastoral 
in mid-nineteenth-century America provides a framework for thinking about the "rural" elements of Trinity Church within the crowded environs of New York City: "the urban-pastoral vision conceives of an alternate 'middle' realm in which the city blends harmoniously with the countryside or contains within its own boundaries urbanity, complexity, and sophistication combined with the physical or social attributes of simple rusticity" (Pastoral Cities 14). For Willis, the churchyard is remarkable for its unique trees in the midst of the city. An 1827 writer describes that he loves "to see a grave yard kept in good order; with here and there a weeping willow, and rose bushes, or some other sweet flowers planted around," and in 1827 a Boston writer observed that "[i]n New York, particularly in Trinity and St. Paul's church yards, the places of graves is shaded by the solemn and healthful umbrage of elms and various other kinds of shrubbery." 38 Indeed, many writers of the period remarked on the quiet, nearly rural elements of Trinity Churchyard in particular, ${ }^{39}$ and the theme appears throughout the literary texts describing visits to the site.

The urban pastoral plays an important role in the representations of and reflections about Trinity Churchyard, but it is not simply the escape from the surrounding urban environment to the yard's pastoral setting that makes it appealing as a physical space and literary subject. More often, it is the interplay between the quiet reverie of the graveyard and the modernity of its surrounding crowds, buildings, and commerce that provokes reflective tension. Willis himself is most moved by the intrusion of noisome technology into the churchyard. The sardonic speaker of "City Lyrics" is upset by the plans for the Pine Street intrusion to "Up-root the tall trees / That shadow the sod; / No more in the breeze / Let green willows nod." In Satanstoe (1845), James Fenimore Cooper describes a scene in which "the young and gay" hold a celebratory event on the grounds: "The bands of different regiments were stationed in the churchyards . . . . Some few of the more scrupulous objected to this desecration of the churchyard, but [ . . . ] the dissenters were little heeded." ${ }^{\prime 40}$ Again, it is often not the peaceful coexistence of the urban and the pastoral that provokes writers and narrators; it is instead the disruptive tension between the two that generates philosophical elevation.

These preliminary analyses show that Trinity Churchyard played a specific role in cultural imagination (especially in New York) from the 1820 s through the 1850s. It was a site where New Yorkers thought about their cultural values and identity. ${ }^{41}$ Sometimes, they used its historical associations to link their current identities to a Revolutionary past. Other times, they used its Dutch associations to root themselves in a foundational civic myth of a non-British, colonial past. 
The churchyard embodied the struggle of Antebellum New Yorkers to negotiate the city's unsettled cultural identity-torn between its early history and the radically modernizing present day.

\section{Hours in Trinity Churchyard}

In this section, I first briefly discuss the history of the rural cemetery movement and its related literature. I then trace the publication history of literary antecedents to Whitman's chapter in Fack Engle, with concentrated literary analysis of three employments of the Trinity Churchyard trope. I argue that one of these examples was written by Whitman himself more than five years before Fack Engle was published.

In contrast to lower Manhattan's urban Trinity Churchyard, the rural cemetery was "a burial ground located on the outskirts of a city that was designed according to the romantic conventions of English landscape gardening" and that was "explicitly designed both for the living and for the dead."42 Providing manicured landscapes that stimulated romantic sentiment in their visitors, rural cemeteries like Boston's Mount Auburn, Philadelphia's Laurel Hill, Brooklyn's Green-Wood, and Richmond's Hollywood were popular tourist destinations for America's urban residents beginning in the 1830s (Bender 199).$^{43}$ One result was the flourishing of "cemetery literature." Henderson notes that, because it is "rooted in the landscapes and histories of specific cemeteries," the popular "cemetery literature" that emerged with the rural cemetery movement differed from more traditional "graveyard poetry" that "situate[d] death within symbolic or universal settings" (90). While the literature of rural cemeteries was undoubtedly pervasive in American periodicals, scholars have yet to reckon with the Antebellum periodical literature of the distinctly urban Trinity Churchyard. I suggest that Trinity persisted as a site of cultural significance because, in addition to featuring many of the traits that would mark rural cemeteries as appealing to visitors and writers, Trinity was unique-first, in its inherent sanctity inextricably connected with America's foundational past, and, second, in its location within the city, in its status as a "garden in the machine." 44

The first instance of the Trinity Churchyard trope appears in 1828 in New York's Freedom's fournal, the first newspaper owned and operated by African Americans. ${ }^{45}$ Titled "An Hour in Trinity Churchyard," the piece begins with Arion, the narrator, explaining that he recently visited the site "for the purpose of spending a leisure hour in meditating on the fate of transient and short-liv'd man." $46 \mathrm{He}$ notes that the "heart" and "bosom" "receive in this solitude [of 
Trinity Churchyard], a kind of mournful pleasure, which is no where else to be found." There, "among the graves, our minds in a great measure, let go their hold on earth, and sublunary concerns, and are lifted up to Heaven." The graveyard provides an opportunity for the urban citizen to escape the "strife and turmoil" of the city and experience a momentary encounter with the romantic sublime - a common feature in other graveyard literature and in the rural cemetery literature that would emerge with the opening of Mount Auburn three years later in 1831.

Following the text's introduction about the mental and spiritual elevation attained in the graveyard, several other features appear that will become prevailing elements of the Trinity Churchyard trope. First, Arion notes that his mind and body are occupied in the "copying [of] some inscriptions." It is this act of looking at and often touching and copying the inscriptions on the tombstones that provokes deeper musings on life and death, past and present. Yet, unlike most graveyard and cemetery literature that brings the narrator into close contact with departed friends, loved ones, or anonymous names, the Trinity Churchyard trope brings the narrator (and reader) into contact with the famous patriotic Americans buried there, thus provoking reflection on the individual and nation as well. Because "touch is the sensory mode that integrates our experiences of the world with that of ourselves," when Arion touches the engraved words and names of local and national history, that history becomes embodied. ${ }^{47}$ In the same way that twenty-first-century visitors to 9/11 memorials near Ground Zero often seek to "reframe "copresence" and establish a less remediated connection to the distant events through tactile interactions with memorials, ${ }^{48}$ Antebellum Americans visited Trinity Churchyard and touched the tombstones there for a meaningful experience of intimacy with local and national history.

This nationalistic element - the second common feature of this trope- is evident in Arion's close textual juxtaposition of copying inscriptions with his musing about the figures of American history buried beneath him. It is "while copying some inscriptions" that Arion's "eye happened to light upon the spot that inurns the ashes of a great and good man [i.e., Alexander Hamilton], the compatriot of our immortal Washington." As with so many periodical accounts of the graves in Trinity Churchyard, the narrator here further enhances the association of Hamilton with America's origins through this act of linking him with Washington.

A third repeating feature of the trope is a physical description of the monuments within the churchyard. Arion here elaborates in detail on Hamilton's tomb: "over his remains rises a pyramidal column of a quadrangular form, 
six feet square at the base, set in a niche, nine feet square, and that embosomed in another ten feet square." The description continues in the same manner of admiring scrutiny, including a remark that "over the whole wave the branches of two weeping willows, fit emblems of the nation's feelings for that bereavement of Providence." After detailing Hamilton's tomb, he describes the "columns" and "summits" of Captain Lawrence's monument and the "majestic Elm [that] sweeps mournfully over the sacred spot." Other writers throughout the period give similar reports, emphasizing both the architecture of the structures and the natural elements surrounding them-all ensconced in reverential nationalism. In a text filled with romantic musings on self and nation, architectural details seem like an awkward fit. Yet, placed in the context of an American generation "attempt[ing] to find new means of affirming a sense of national identity," 49 the dimensions and construction of these stone monuments that memorialize and mythologize American heroes perform an important function. They establish a national American past through the unique architecture of a historical site in the same way that other great civilizations-the Greeks, Romans, Egyptians, British, French-had impressive and recognizable cultural and civic architecture.

At the center of this and other narratives in Trinity Churchyard is the reproduction of the writer/narrator's primary experience for the remediated experience of the reader. The personal ordeal of establishing an imagined connection to a national past through a visit to Trinity Churchyard is one that, based on periodical evidence, appears to have been repeated by many individuals in the Antebellum Era. Yet participation in such a phenomenon was restricted to denizens or passers-through of the New York area. Since "the goal of cemetery literature was to replicate as closely as possible the experience of visiting the cemeteries themselves" (Henderson 96), printed and reprinted accounts of a graveyard or cemetery visit provided a remediated experience of the same meditations for thousands of readers across space and time. ${ }^{50}$ In essence, the trope was a meme of nineteenth-century newspapers, and if the Trinity Churchyard site itself provided democratic access to America's history, civic mythology, and constantly negotiated identity, prints and reprints of visitation accounts to Trinity Churchyard extend that democratic access beyond the confines of geography, mobility, leisure, gender, and race. ${ }^{51}$ That this first instance of the trope appears in Freedom's fournal is not insignificant-the African-American-owned fournal was founded for the express purpose of serving as "a medium of intercourse between our brethren in the different states of this great confederacy: that through its columns an expression of our sentiments, on many interesting 
subjects which concern us, may be offered to the public," ultimately resulting in "the improvement of our brethren." 52 Thus, we see that the experience, whether embodied or remediated through text, was remarkably accessible to an array of Americans.

A second example of this trope's appearance in the American print sphere occurred in 1839 in the New-York Spectator as a reprint from the New York Mirror. ${ }^{53}$ Also titled "An hour in Trinity Church Yard," the text reproduces many of the same features of the identically named piece that appeared eleven years earlier in Freedom's fournal. First, H.A.E., the narrator, continually secures Trinity Churchyard as a fixture in the foundational history of New York and the United States. He discusses the tombs of Marinus Willett, "hero of Fort Stanwix,' Lord Sterling, the revolutionary general, -William Livingston, the patriotic governor of New-Jersey, and [ . . . ] Judge Brockholst Livingston, of the Supreme Court of the United States." These are not just "distinguished and revered names all," but names "familiar in the early records of the city and province, names whose descendants still remain, with a pride of ancestry equal to the most aristocratic families of the mother country." $\mathrm{He}$ discusses the tomb of New York printer William Bradford, and the relationship that he had with Benjamin Franklin. Like its counterpart in Freedom's fournal, this text describes the patriotic lives of Hamilton and Lawrence and provides detailed accounts of the architecture of their monuments, again treating them as pieces of noble and national architecture. The narrator muses nostalgically about the bells of Trinity Church that he can recall from Fourths of July long ago. In these ways, this iteration of the trope continues the strong association of Trinity Church with a national American history - an association not easily established in the literature about America's recently opened rural cemeteries.

H.A.E. also displays a fascination with the Dutch origins of New York. He refers to the "Knickerbocker names of the 'olden time," and reflects on the grave of "one who had died before the revolution. I could not help copying the name, for it bespoke a countryman of the first settlers, from the land of Van Tromp and De Ruyter." Here, the author reproduces the physical act of copying names (and thus experiences an embodied connection to the mythologized past), and he continues the established pattern of meditating on the semi-mythologized Dutch origins of New York. Further, he references New York poet Fitz-Greene Halleck, and, in doing so, not only responds to the national urge for an American literature that could "aid in the achieving of the national mission," 54 but also points specifically to a writer from the "Knickerbocker Group," which included Washington Irving, James Fenimore Cooper, and William Cullen Bryant, and 
which focused on themes of "the collision between tradition and progress in the new nation and the subtle interconnections between European and American culture." ${ }^{55}$

The anxiety between "tradition and progress" surfaces elsewhere in H.A.E.'s text, such as when he first arrives at the churchyard, mourning the pulling down of the church (historically concurrent with the publication of the story), and notes that "piece by piece, falls the spire." The loss of the church is meaningful for both personal and cultural reasons: the "merry peal" of the church bells were associated with the narrator's childhood and "patriotic fervor," but now "they are gone-church, spire, bells, [ . . . ] OLD TRINITY is levelled with the dust." To him, the destruction of the second church is a personal and national loss to be mourned. In fact, the account opens with a meditation that "TIME - ceaseless, corroding time-nations, empires, pyramids, and temples, crumble-yea, DEATH itself fades before thee . ..." In this context, the narrator's concerns are not just about past national identities; they are equally about the future of national identities and how the generations of the ever-modernizing nineteenth century will find meaning in a landscape in which the principal ideology is "pull down and build over again."

H.A.E. develops the role of the urban pastoral in churchyard descriptions. In the account in Freedom's fournal, the natural elements of the graveyard are simply decorations in the scene's background. Here, however, the narrator devotes significant attention to the interplay between the natural features of Trinity Churchyard and the modern, urban elements of lower Manhattan: "The swelling mounds were dressed in nature's greenest livery, the elm trees and sycamores were in full leaf, and the horse chestnut was in blossom." He continues: "The chirp of the grasshopper ... as he leaped out of my path, and the occasional note of some tiny bird, from the branches of the tall trees, mingle with the faint hum that swept from the busy crowd without, and added to the harmony of the scene and sense." In this passage we see that Trinity Churchyard does provide a romantic, pastoral environment, but the narrator makes it clear that the pastoral vision is imperfect, at least in the traditional sense. The visitor cannot escape from the "faint hum" of the "busy crowd without," yet this mingling of urban and pastoral, of reveristic and modern, stimulates deeper meditations in him. He describes the juxtaposition of the churchyard and the cityscape: "It was the resting-place of the dead surrounded by the living. Numberless thousands were here reposing the long sleep of death, whose footsteps had once beat as firmly as those which now fell upon my ear, and probably trod the same broad pavement with as high hopes, and as brief anticipation of death." His reflections are 
about himself as well as about the masses. In the suspension between urban and pastoral, he ponders his own life and mortality, but, in a way strikingly similar to the Whitman of Leaves of Grass, he marvels equally at the "busy crowd," the "numberless thousands" of his city, and the relationship between the living, the dead, and the author. Finally interrupting his lengthy reflection are natural and human phenomena alike: the setting sun, the emergence of the night crickets, and the "more rapid and hasty ... footfall of the traveller with out as he wends his way homeward, to rest from the fretting cares and toils of the day." For H.A.E., the urban and the pastoral are both necessary for introspection, but those same elements eventually serve as disruptions of his sublime moment.

An important literary technique used in this work (and much cemetery literature of the period) is the narrator's frequent and literal inclusion of the reader in the scene. H.A.E. often addresses the reader as if he or she were there in the churchyard with him. One result of this is that the text reads like a tour, with the narrator as tour guide and the reader as tourist. He points out that "yonder is a monument of more pretensions to the name than any that surrounds it." $\mathrm{He}$ encourages the reader to "approach [the same monument] and read the inscription," which he has transcribed in the text. The text has a sense of movement when he remarks that "we are now at the rear of the church, where the tombs are so numerous that we can hardly clamber along," and when he tells the reader to "pass on" to a headstone that produces an effect not simply in him, but in "us." In another moment of movement and mutual experience, he states: "Here are some ten headstones in a cluster." This sense of movement and the repeated inclusion of the audience results in an enhanced, more literal embodiment of the experience for the reader unable to visit the actual site. The reader participates in a mediated yet visceral interaction with the landscape of the churchyard and with its associations of national origins and civic myth, thus compounding the effects of an individual's nationalistic experience being printed, reprinted, and distributed to the American masses.

A third example of a meandering meditation in Trinity Churchyard comes from the Brooklyn Daily Eagle on July 07, 1846. Whitman began working as editor of the Eagle in March of that year, ${ }^{56}$ and it seems likely that the article, "A Brooklynite in N.Y. Church-Yards," was penned by Whitman himself. The text bears several marks of Whitman's presence. First, the author of this article refers to Hamilton as "a man whose lot it was to be hated and worshipped with equal strength," and six years later, in Fack Engle, Whitman characterized Hamilton as "the sower of seeds that have brought forth good and evil," and at whose funeral "dire wishes of vengeance rankled in many a bosom" (Fack Engle 334). 
These are the only two suggestions of negative feelings toward Hamilton in any Trinity Churchyard literature that I have found. The author also demonstrates a proud stake in Brooklyn in competition with Manhattan, evident in his note that "By the by, it is somewhat singular that a number of our Brooklyn folk, are in the frequent-some of them in the regular-habit of crossing the ferry to go to their devotions! And this $i s$ the City of Churches!" There is an interest in the colonial and revolutionary roots of New York as well, and especially in Washington and the "unhappy battle of Long Island," which Whitman explores in much of his prose writing. ${ }^{57}$ It is significant also that Whitman would later display similar fascination with graves in Fack Engle, in his journalistic piece "Brooklyniana No. 10," and in poems like "This Compost" and "Outlines for a Tomb." Further, the piece's regret at the sacrifices of cultural architecture in the "age of progress" resonates with Whitman's 1845 article in The American Review, "Tear Down and Build Over Again." Yet, even if Whitman were not the author, the article's publication in the Eagle at the time of Whitman's editorship indicates his close contact with the trope of the Trinity Churchyard visit.

"A Brooklynite in N.Y. Church-Yards" follows its narrator from Trinity Church, where he listens to sermons on "the early history of the church" and its "missionary [work] to the Mohawk Indians." After the service, the narratorspeaking as "we"- "passed out to spend a while in the ancient grave yard attached." Like other narratives at the site, this one philosophizes that "The monuments in church yards are always instructive to any thinking man. A few moments spent in walking through them, will richly repay one for his time and trouble." ${ }^{58}$ That repayment comes in the form of a personal moment of romantic enlightenment, when "the mind is imbued with feelings akin to those which impress it amid the burial places of times past in the old world," and "everything remind[s] one of the generations past away." The romantic enlightenment is both personal, reflecting on one's own mortality, and national, establishing a sacred historical site comparable to those of European cultures with deep historical roots.

The national element draws on some of the popular techniques employed by earlier Trinity Churchyard texts. The article mentions the tombs of "the storied names of America": Lawrence and Hamilton, and some other American military heroes entombed at nearby St. Paul's Chapel. The rhetoric is markedly patriotic, while repeating the technique of including the reader in the visit at a less mediated distance: "In one place you read of a man who fell in battlehis blood spilled for the dear native land, and his life given cheerfully in her service." ${ }^{59}$ Furthermore, the narrator connects Trinity Church to America's 
revolutionary and founding history, just as earlier examples had done: "When Washington, after the unhappy battle of Long Island, retreated from that city up to Kingsbridge, the British entered our metropolis, which either by accident or intention, caught fire . . . The flames swept up the north side of Broadway, destroying Trinity church and everything else ...." The site is reaffirmed as a metaphysical space in which environment, materiality, history, nation, and the self all merge into a sense of American identity.

The narrator's brief yet poignant discussion of grass and leaves reproduces one of the trope's common elements, but it also develops it in a way that signals Whitman's authorship of the piece and his early engagement with grass as a potent symbol of decomposition and regeneration. The narrator observes: "Here are flat tombs, even with the surface of the earth, and some below it, covered with grass - the inscriptions spelt in an old fashioned style, and everything reminding one of the generations past away." He continues: "Ranks of the dead are ranged in every direction, and in summer the grass and foliage of the trees has an almost oily fatness, from the rich soil of the graves." Certainly, the author is not the first to remark on the churchyard's grass; nor is he the first to theorize that the interred corpses of the churchyard affect the surrounding vegetation. Yet, the description of the "oily fatness" acquired from "the rich soil of the graves" provides an uncanny reflection on sanitation, decomposition, and regeneration that Whitman's later poetry would explore in depth. ${ }^{60}$ In "Poem of Wonder at The Resurrection of Wheat" (1856), for example, Whitman's speaker addresses the earth: "Where have you disposed of those carcasses of the drunkards and gluttons of so many generations? / Where have you drawn off all the foul liquid and meat?"61 The connection between dead flesh and the vegetation above it is chief among the speaker's concerns. He observes that "The summer growth is innocent and disdainful above all those strata of sour dead" and "probably every spear of grass rises out of what was once a catching disease." This text demonstrates an earlier development of Whitman's fascination with grass as "the beautiful uncut hair of graves" and as evidence that "All goes onward and outward, nothing collapses, / And to die is different from what any one supposed, and luckier." 62

The 1846 appearance of "A Brooklynite in N.Y. Church-Yards" did not mark Whitman's first textual meditation about life's transience. In August 1840, Whitman published "Sun-Down Papers.-[No.6]" in the Long-Island Democrat. ${ }^{63}$ There, Whitman delivers a prosaic meditation that bears several common elements of graveyard poetry: it ponders life's ephemerality, it mourns the death of a specific person, and it ultimately functions as a lamentation. 
Yet, notably absent is a graveyard or cemetery. Instead, Whitman reports being stimulated to sentimental elevation by reading in a newspaper the "intelligence of the death of one whom I knew slightly." Thus, the newspaper itself replaces the graveyard as a site of introspection and romantic musing for both the writer and the reader.

A month later, in "Sun-Down Papers.-[No. 7]," Whitman issued another provocative meditation on life and death, this time using metaphors of contemporaneous technologies of travel. ${ }^{64} \mathrm{He}$ describes life as "a long journey by steamboat, stagecoach, and railroad" in which the passenger can "hardly get fairly and comfortably adjusted" before having to stop and make a transfer. The tension between mortality and modernity is especially evident in this text, as Whitman decries the accumulation of wealth, "baggage," and worldly success while ultimately en route to "that mysterious train we all go with sooner or later" that "admits no luggage therein." Further, it is the enjoyable parts of life - the passenger's comfort, dinner, and lounging - that are dizzyingly interrupted when "the bell rings, the steam puffs, the horn blows, the waiters run about half mad, every thing is hurry-scurry for a moment, and whizz! we are off again." It is significant that Whitman uses the technologies of modernizing nineteenth-century America to explore the unsettled relationship between life, worldly success, technological development, personal and cultural values, and death. In doing so, he taps into the cultural tension between reflective reverie and modernity.

Three years after "A Brooklynite in N.Y. Church-Yards," Whitman published "Letters from a Travelling Bachelor-No. II" in Sunday Dispatch, the same paper that would publish Fack Engle in 1852. ${ }^{65}$ In "Letters," Whitman visits two "ancient burial places of East Long Island" most notable for their old, worn-down graves. In contrast to the romantic descriptions of burial sites in most graveyard and cemetery literature, Whitman's description here verges on gothic at times. The sites "had an unusually bare and dismal and lonesome appearance," they were on "bleak and stony hills," and one was "a weird looking place; the wind piped its thousand trebles over the hill tops on each side . . . yet down there not a breath of the wind could be felt." Ultimately, the text resists romantic elevation, perhaps the result of several factors: the difficulty in reading inscriptions, the unappealing landscape, the strictly rural setting, and the lack of distinctly American relics there. These rural cemeteries lack the unique traits of Trinity Churchyard that stimulate Whitman and other writers to deep contemplation of nation and identity.

Whitman also wrote a number of periodical texts about Brooklyn's rural 
Green-Wood Cemetery, and they follow in the tradition of rural cemetery literature. One scholar has noted that the "pieces have little to distinguish them from the mass of journalistic accounts of the cemetery and are guilty of many of the faults that have sentenced other articles to obscurity: they are repetitious and propagandistic, and are usually pieced-together versions of previously printed articles rather than original compositions." $" 66$ The earliest of these texts appeared in the Universalist Union in 1839, and while it ruminates on themes of mortality and worldly gain, it finds neither the connection to foundational American history nor the intensely close juxtaposition of the urban and pastoral to stimulate the unique kind of meditation found in the Trinity trope. ${ }^{67}$ An 1844 example, "A Visit to Greenwood Cemetery," shows Whitman reflecting on several graves, although never transcribing their inscriptions and never feeling any nationalistic sentiment. ${ }^{68}$ The tombs to which Whitman pays the most attention-those of locally-known poet McDonald Clarke and the Native American woman Do-Hum-Me-do not reach back into America's early roots and therefore do not provoke identification with America's national past. Two years later, however, Whitman would again remark on these tombs in the Brooklyn Daily Eagle, this time elaborating more on them. Even in his more thorough reflection on Do-Hum-Me, which gestures toward the nineteenth-century trend of "claiming Indians, with their long history and mysterious origins, as part of their own national story" (Scheckel 7), Whitman is unable to achieve the same sort of nationalistic urge that is so present in "A Brooklynite in N.Y. Churchyards" just three weeks later. These various texts demonstrate the uniqueness of the Trinity Churchyard trope among Antebellum cemetery literature.

It is worth noting that the three major examples of the Trinity Churchyard trope provided in this section originally appeared in significantly different contexts but still carry a central meaning. The first iteration's publication in Freedom's fournal is perhaps surprising since the fournal was owned and operated by African Americans with the established purpose of the "improvement of our brethren," but the text makes no explicit or even implicit reference to race. It is impossible to know the motivations of the text's author or publishers, but it is significant that the text centers on meditations about a shared national past, especially as it was published in a venue interested in establishing a cultural identity and network about six months after emancipation in New York and eighteen months after the deaths of Adams and Jefferson, a moment that "announced the end of the Revolutionary age and summoned nostalgic feelings for its disappearance." ${ }^{69}$ The subtle theme of finding a genealogical and cultural identity in the churchyard will resurface as we turn to the Trinity scene in Fack 
Engle. Meanwhile, the iteration originally printed in the New York Mirror and reprinted in the New-York Spectator demonstrates just one example of how the trope was found suitable for publication in a variety of Antebellum newspapers. This is not to say that each newspaper's readership responded to the texts in identical ways, but it is notable that the trope appeared across an array of periodicals over the Antebellum decades while always negotiating the tensions of a patriotic past and a modernizing present to arrive at a sense of national identity grounded in Trinity Churchyard. In fact, even the unusual critical characterization of Hamilton in the Eagle, which did little to veil its bias as an "organ of the [Democratic] party," did not hamper the nationalistic and propagandistic sentiment of the text (Brasher 18).

Further, "A Brooklynite in N.Y. Church-Yards" and the two "Hour in Trinity Churchyard" texts are not the only examples of the trope of Trinity Churchyard in the 1820s-1850s. A July 1846 article in the Boston Evening Transcript reflects on the ancient inscriptions of the headstones and on the local and national events that the site has witnessed. ${ }^{70}$ Like so many other texts that remark on the Dutch origins of New York and the tension between tradition and modernity, the writer observes that "If any one of the old Knickerbockers of those old days . . . could now burst the trammels of the tomb and for an instant survey the scene around him, he would no longer recognize in this modern Babel the calm and quiet Manhattan of the olden time." An 1852 article in the Spiritual Telegraph describes a stroll through Trinity Churchyard and a visit to Charlotte Temple's tomb, occasioning melancholy reflections in the narrator. ${ }^{71}$ Rather than the heroic figures of Hamilton or Lawrence, this text uses Charlotte Temple's tragic figure to connect the visitor to the early Republic and to reflections of modernity's tension with the past. Temple's tombstone, a relic of an age gone by, had been partially looted and "doubtless converted by some human hyena into small change at a junk shop." 72 The same themes recur throughout the numerous iterations of the trope.

The Trinity Churchyard trope is significant in its departure from graveyard poetry of the past and in its distinct features that are not found in the American literature of rural cemeteries. While graveyard poetry, such as British poet Thomas Gray's famous "Elegy Written in a Country Churchyard" (1751), established generic features that the Trinity Churchyard trope would later incorporate-a pastoral setting, the narrator's contemplative affect, and the transience of life-the Trinity trope was distinct in several ways. It was not simply pastoral, but a blend of urban and pastoral. It focused not merely on the individual's imminent death, but it considered the individual in relation to a 
national past and to an ever-changing present. Like much American cemetery literature, the trope was featured primarily in prose rather than verse, and it was uniquely American in its associations with a national past and civic mythology, set in the well-known, real-world, historical location of Trinity Churchyard.

The treatment of New York's Trinity Churchyard in local and national periodicals is also distinct from the treatment afforded to the historic burial grounds of other cities. No such literature existed for Boston's Granary Burying Ground, where John Hancock, Samuel Adams, and the parents of Benjamin Franklin were interred. Occasional references to Granary Burying Ground's historical associations appeared in local papers, but they are unmistakably nonliterary, impersonal, and unromantic. ${ }^{73}$ Likewise, Philadelphia's Christ Church Burial Ground, the resting place of notable Americans like Benjamin Franklin and Benjamin Rush, produced no pattern of graveyard literature comparable to that of Trinity Church. ${ }^{74}$ Yet personal, literary, and inherently nationalistic reflections on Trinity Churchyard were popular in newspapers in New York and other cities alike.

In studying the various periodical employments of the trope of Trinity Churchyard from the 1820s through the early 1850s, we find that it was a tool with which writers of the Antebellum period could experiment with articulations of cultural identity and grapple with difficult questions like "what is our relationship to the past, and how should we narrate it?" (Pfitzer 7). Unlike earlier "complex, multivolume works by patrician historians" that tried to answer those questions and that were only available to a "select group of highly educated patrons," the Trinity Churchyard trope's appearance in affordable newspapers made it widely accessible for an American public. It was a mechanism for asserting a modern connection to a mythologized, uniquely American past and for negotiating the disruptions that modernity provoked in that very connection. With each periodical publication (original or reprinted) that engaged with the trope, Trinity Churchyard became more deeply established as a site of American origins. Thus, it is not surprising that in 1852 an American newspaper writer and editor, particularly interested in concepts of national roots and identity, should incorporate the trope into a serialized novel.

\section{Fack Engle, the American Orphan}

In the early 1850 s, the United States was engulfed in a recently exacerbated crisis of identity. Sectional tensions divided the country, and the Compromise of 1850 - including the Fugitive Slave Act-deepened the divide. The nation was 
strained by conflicting viewpoints on immigration. Rapidly modernizing and urbanizing, while becoming ever more distant from its real and semi-mythological origins in the Revolution, Americans-especially those in the developing urban centers - simultaneously confronted modernity with caution and eagerness. All the while, American writers and artists continued to respond to the call for an American literary voice, for a "genius" who would sing the "yet unsung" differences of the people, politics, and cultures of the United States into one "poem," to use Emerson's language. ${ }^{75}$

Whitman's answer to that call began far earlier than his 1855 publication of Leaves of Grass. Bonnie Carr O'Neill cogently illustrates that Whitman's editorials of the early 1840s "aggressively promote Americanist political and cultural values and highlight the relevance of everyday life to shared experience and collective identity." "The same promotion of American values is evident in "A Brooklynite in N.Y. Church-Yards," written or at least edited by Whitman in 1846. But in 1852, Whitman's serial novel, Fack Engle-published over the course of six weeks - demonstrates Whitman's significant experimentation with articulations of an American voice and with the negotiations of contemporaneous socio-political tensions in a longer piece of fiction that, at moments, moves toward resolutions. Perhaps the most striking aspect of this attempt is its incorporation of the Trinity Churchyard trope as the key tool by which Whitman articulates his vision. This is not to say, however, that in Fack Engle Whitman puts forth (or even has) a single, organized vision of the nation or of the individual's relationship to it.

Yet the novel tells us more than popular reviews have suggested, and it certainly should not be written off as low-grade or simply imitative of a Dickensian style. As Ed Cahill reminds us, there is immense value to be found in literary works (especially periodical ones) disregarded as "derivative of the European literary culture" or lacking argument or substance. Such texts both "generated new conceptions of self and society" and questioned the merits and limits of individuality, autonomy, and agency, and emphasized both the individual and community. ${ }^{77}$ What I suggest here is that Whitman uses the Trinity Churchyard trope as a mechanism for trying to unify difference through its established role as a site of a shared national memory and history.

Fack Engle is the story of a New York orphan-Jack Engle himself, also the narrator - who lives his early childhood on the streets of New York as a "little vagabond," a "juvenile loafer" (268-269). Jack is eventually taken in by a kind couple, Ephraim and Violet Foster. The narrative begins when Ephraim secures Jack a job in the office of a rigid, unlikeable Quaker lawyer named Covert. He 
works with two others at the office: Nathaniel, a young, rugged, and adventurous young man whom Jack describes as the "approved specimen of America," and Wigglesworth, an old man who is usually drunk but possesses a "good soul" (263-264). Jack develops an attraction for a young Spanish woman named Inez, but after meeting a young Quaker woman named Martha (also an orphan), his interests shift toward the latter, who lives under the care of Covert. The plot deepens when Wigglesworth, who has become a religious zealot and is nearing the end of his life, tells Jack that he has discovered important information about the young man's mysterious past, convinced that he "couldn't rest in peace, if it was not done" (313). Wigglesworth reveals that Martha's father had killed Jack's father in a fit of rage, and that, before Martha's father died, he had hired Covert to arrange his affairs and ensure that his estate would pass in part to Martha and in part to his victim's son-Jack. Knowing that Covert is actively engaged in plans to rob the two of their endowments, Jack and Martha plan and execute the latter's escape to Inez's care in Hoboken, New Jersey. The next day, Jack visits Trinity Churchyard "to pay the last honors to the body of poor Wigglesworth," who has recently died (331). Whitman dedicates an entire lengthy chapter to the visit and elaborates on the trope of Trinity Churchyard. After leaving the churchyard, Jack is finally "in a fitting temper" to read Wigglesworth's manuscript about his and Martha's intertwined past (338). In the final two chapters, Covert flees presumably to Canada, and Jack marries Martha.

Thus, Fack Engle is a novel about two orphans, disconnected from their pasts and trying to make sense of their places in a modernizing and capitalistic New York City. It confronts issues of race, immigration, class, gender, politics, and individuality. It explores the relationship of personal, cultural, and national identities in mid-nineteenth-century America. What I am suggesting is that Jack Engle's status as an orphan without a foundational past or clear future resonates as poignantly analogous to the fracturing socio-political scene of early-1850s America. Likewise, the story's resolution to the tensions within it demonstrates the link between past and present that becomes such an important aspect of Whitman's later writing. The critical element in all of this, I will demonstrate, is the trope of Trinity Churchyard.

Jack's quest for his personal history, meaning, and identity is at first uninspired. He knows that his name is inherited from his parents, for he remembers being called by it as a homeless youth, and it is also inscribed on the dirty gold earring that he wore when he first met Ephraim and Violet. Other than in name, Jack is completely severed from his Engle ancestry, unable to establish a meaningful narrative of his origins, although he claims that his parentage was "about 
the slightest of mine or Ephraim's cares" (296). He further explains: "When I thought about it at all, which was very seldom, my mind had no other point to arrive at than the plain and evident supposition that my degree, if traced at all, would be found in the lowest grade of society; and that my parents were doubtless dead long before this time." Despite his repeated assertion that his parentage was unimportant to him, its mystery nonetheless forms a central conflict of his narrative. His name itself communicates its own significance: Jack's ancestry as an "Engle" parallels a national genealogy rooted in "English" parentage. Nor is Jack's name the only one of importance. Names carry considerable meaning throughout the piece: Covert is surreptitious ("covert") in his own right, and he is possessive of women ("coverture"). Ephraim Foster is indeed the foster parent of Jack. Wigglesworth is preoccupied with the afterlife, much like the famous seventeenth-century Anglo-American clergyman with whom he shares a surname, whose famous poem describes the divine punishment of sinners on the Day of Judgment. ${ }^{78}$ Calvin Peterson delivers sermons reminiscent of George Whitefield's Calvinist Methodist preaching. Thus, in the context of the disconnected link to his past, Jack's name of Engle stands out as symbolic of an America severed from its parent and now trying to create its own narrative and identity.

Attempts to create meaningful identities are stifled throughout the text. In the story's first issue (Chapters I-IV), real, local place names are mentioned often, but the frequency with which they appear diminishes as the story progresses. The very first sentence of Chapter I establishes Wall Street as the location of action. It is significant that the story begins on capitalistic Wall Street but later achieves its poetic climax just down the street in Trinity Churchyard, the firmly-entrenched symbol of a sentimental national past. Further, Jack describes early on how he "looks mighty sharp at the girls as they go home through Nassau street from their work down town." Ephraim Foster, he explains, "kept a shop in one of the thoroughfares that cross Grand street, east of the Bowery." Nathaniel was "a small boy with boundless ambition; the uttermost end and aim of which was that he might one day drive a fast horse of his own on Third avenue" $(264,265)$. By referencing so many place names, Whitman does more than set the story in familiar local locations simply for the sake of setting. I read the place names, instead, as an early narrative attempt to establish a mythos of the New York cityscape. The various places-also including Broadway and Trinity Church - form a virtual map, and the reader is conscious not just of his or her own recognition of it, but of the shared, citywide, relatively simultaneous identification of other readers with those streets and buildings and neighbor- 
hoods. Yet, whether through authorial design or not, the frequency of place names decreases as the story continues, and the establishment of a structure of unification is left unfinished. Shared physical locations alone will not suffice for America's quest for a united cultural identity.

Demonstrating a similar moment of frustrated attainment, Jack describes attending one of Calvin Peterson's revival meetings. Peterson's preaching is passionate: he "struggled violently, for he had got the steam up, and was under full headway" (299). Men's bodies sway, and girls and women cry. Yet, when Peterson follows an impulse to entreat "all those who love the Lord [to] rise from their seats," Jack notes that "There was a pause, and sad to relate, only one individual, a pale, shamefaced young man, a tailor's apprentice, responded to the appeal" (299-300). Peterson's spiritual encouragements are only partially effective in stimulating personal or communal moments of transcendence. Jack describes a "popular old camp-meeting song" that the congregation sings, "intended to describe a contest between the soul's inclination to religion on the one side and worldly pleasure on the other." The singing, he explains, has an "unwonted charm" and is one of "the wild, almost grotesque tunes that there are so many of in America." In other words, the song itself is not beautiful, but Jack still remarks that he finds personal value in its theme of tension between earthly desires and higher "dictates of duty."

The two verses that Jack transcribes for the reader are of great import. They come from a real hymn published in The Camp-meeting Chorister in 1830 and in at least two other books between then and $1852 .{ }^{79}$ The song begins with the singer's invitation to his or her own "soul" (the "heart" in the original publications) to "take, / An evening walk becoming thee." In the original hymn, the walk is symbolic of a personal journey toward Christian virtue, but in the abbreviated selection transcribed in Fack Engle, the purpose of the walk is less explicit, and the "becoming" of the soul suggests a moment of spiritual elevation. The walk's two destination options are Calvary, the site of Jesus' crucifixion, and Gethsemane, the Jerusalem garden frequented by Jesus and the site of his betrayal. The song identifies these specific sites as locations of spiritual attainment, or, in an 1850s literary context, of romantic sublimation. Neither sacred site is visited, however, because "Calvary is a mountain high, / 'Tis too difficult a task for me, / And I have heard there are lions in the way, / And they lurk on the path to Gethsemane." In other words, the quest for spiritual awakening is stifled. These symbolic sites, the song claims, are inaccessible, and thus spiritual elevation remains inaccessible. Jack enjoys the song and relates that it always affects his "general feelings," but it nonetheless fails to inspire a pinnacle 
moment in Jack's mind or in his narrative form and style. ${ }^{80}$

A crucial change occurs in Jack's bildungsroman immediately prior to the Trinity Churchyard scene: Jack shifts from a passive character to one of agency. As a child, Jack is the younger, smaller sidekick of Billiggs, who takes care of him. As a twenty-year-old, Jack deferentially abides by Ephraim Foster's wishes that he take up a position with Covert, despite Jack's aversion to the legal profession. At the firm itself, Jack enjoys the company of Nat, although the reader observes the latter taking advantage of Jack when, after Nat's dog dirties Inez's dress, he suggests that fack should make it up to her by buying tickets to Inez's next theater show for the two of them and Wigglesworth and one or two of Nat's "sworn cronies" (Fack Engle 278). Despite all this, when Wiggleworth later communicates revelations of Jack's identity, the boy finds agency. He plans and executes Martha's escape, delegating duties to various friends. As they abscond across the river in the dark of night, Jack participates as rower, despite Nat telling Jack earlier that "Mr. Peterson and I've got the boat waiting [ . . . ] and we'll soon row you over." To this, Jack asserts: "As for that, if it were necessary, I could take a hand myself, thanks to the practice which most New York boys get along her docks and shores." As leading orchestrater and performer of Martha's escape, Jack emerges as a character of action.

Equally significant is the moment on the river when-prefiguring the sentiment and descriptions of Crossing Brooklyn Ferry - the youths pause and observe the scene around them. "Though there was no moon, the stars were shining bright. The fresh south breeze came pleasantly up from the Narrows; the water dashed in ripples against the boat" (330). Halfway between Manhattan and Hoboken, removed from the urban landscape, Jack experiences a moment of romantic reverie: "Out in the middle of the river, we lay on our oars a few minutes, and enjoyed the scene still more. The long stretch of the city's shores were silent and hushed; two or three sloops, at various distances on the river, moved along, their white sails showing like great river ghosts; and not a harsh sound was to be heard." As beautiful as the scene is, it produces an eerie effect on Jack. Without the moon, the river "seemed like a path of darkness and doubt," and Weehawken Heights on the Jersey side of the river cast "sombre shadows." When the moon emerges, the scene is more peaceful, but they are soon ashore, engaged in the plot once again. This scene, "out in the middle of the river," is yet another frustrated attempt at transcendence. The romantic elevation lasts a few moments, but it is haunted by darkness and "river ghosts." Even at a distance from the city, amid the natural elements of the river, Whitman's character cannot achieve a genuine romantic moment. 
While the figurative sites of Calvary and Gethsemane are inaccessible, and the Hudson River is insufficient for a transcendental experience, Trinity Churchyard is a physical site for Jack (and the reader) to visit for a uniquely American awakening. The trope appears immediately following the zenith of action and empowerment for Jack, and, at this heightened moment, he reveals a new investment in concepts of personal mortality, roots, and identity.

The chapter in Trinity Churchyard bears many of the same elements-great and small - as its literary antecedents. First, its title echoes those from Freedom's Fournal, the New-York Mirror, the New-York Spectator, and the Brooklyn Daily Eagle: "Some hours in an Old-New York church-yard; where I am led to investigations and meditations" (331). It comments on the natural elements of the churchyard ("the verdure, touched with brown, of trees nourished from the decay of the bodies of men") and their proximity to the surrounding urban environment ("May the aged clerk rest in peace there, in that vault in the midst of the clang and hubbub of the mighty city, which surrounds him on all sides!") (331-332).

The tension between reflective reverie and modernity is as much apparent in Whitman's rendering of the trope as it is in other texts. While in the churchyard, Jack reflects on the juxtaposition of past and present, life and death: "Out there in the fashionable thoroughfare, how bustling was life, and how jauntily it wandered close along the side of those warnings of its inevitable end" (337). Wondering at the invisibility of death to those walking down Broadway a few feet away, he continues: "How gay that throng along the walk! Light laughs come from them, and jolly talk-those groups of well-dressed young men-those merry boys returning from school-clerks going home from their labors-and many a form, too, of female grace and elegance." Meanwhile, "six feet below where I stood," similar "young men" and "schoolboys and women" remind Jack of mortality's inevitable supremacy over modernity and its fashions and affairs. Further, in a moment that Zachary Turpin suggests "strikingly echo[es] the imagery of Whitman's great work," Jack remarks that "long, rank grass covered my face." 81 The preceding analyses have identified the grass as a common feature of the trope; so if it is distinctly Whitmanesque, then Whitman seems to have found inspiration in the trope of Trinity Churchyard.

Like other Trinity narratives, this account begins with melancholy reflections about the value of visits to graveyards. While Freedom's fournal remarks on the "kind of mournful pleasure" found there, and the New-York Spectator observes that "there we can ponder deeply, and wisely, if we will, upon the mysterious gloominess of death," and the Brooklyn Daily Eagle attests to the 
graveyard's capacity to be "always instructive to any thinking man," in fack Engle the churchyard puts Jack in a certain "humor, serious without deep sadness," and Jack suggests that it offers a "lesson; and a valuable one." That lesson is not simply an understanding of one's mortality, but an understanding of one's identity rooted in a national past.

The national associations begin early in Whitman's rendering of the trope. Jack describes his visit as taking place on a "pleasant, golden forenoon, one of the finest days in our American autumn" (332). The first grave he visits is of a twenty-two-year-old man, James M. Baldwin, who, as the tomb's inscription explains, was "wounded on Lake Champlain" and died a year later. Jack calls him "one of the republic's faithful children - faithful to death." The 1704 tomb of a man named Edward Marshall sparks patriotic sentiment located in imaginings of pre- and post-Revolutionary America: "1704! At the time when these paragraphs are being printed, nearly a century and a half ago. . . What great events have happened too, since that time! A nation of freemen has arisen, out-stripping all ever before known in happiness, good government, and real grandeur" (333-334). The tomb of Hamilton is Jack's next stop, and, despite positing that Hamilton was "the sower of seeds that have brought forth good and evil," he transcribes the tomb's laudingly patriotic inscription, and he recounts the immense turnout at the funeral, where "every eye was wet with tears." $\mathrm{He}$ also reproduces "the history transcribed upon" Lawrence's tomb and provides an account of the updated monument rebuilt in the time between the narrative's setting and Jack's retelling of it - presumably in 1852 (335). Jack proclaims Lawrence as "the brave ideal of such as I-of all American young men," and he waxes poetically in description of Lawrence's patriotic deeds: "what a day must that have been when he drew out of Boston harbor, and the hearts of his countrymen beat high with the confidence of victory. What a moment, when, struck down by the enemy's fire-enveloped in smoke and blood-the sounds and sights of carnage around him on every side-he was born from the deck, overcome but not conquered" (335-336). His heroism is made complete by "his last thought, his last gasp, given for his country!" The rhetoric of American nationalism continues with celebration of the "beloved republic" and praise for the American people's generous "admiration of patriotism." The final linking of Lawrence's patriotism, American national origins, and Trinity Churchyard occurs when Jack describes his burial in New York: "The flag he died for, wrapped his coffin-and he was lowered in that native earth whose boast is that she nurtured such brave defenders as himself." The once passive and disinterested Jack finds himself "more and more enamored with these researches," wrapped 
in elevated romantic musings that center so notably on national origins.

Local New York origins are an important feature of the experience as well, just as they were in the trope's periodical antecedents. Jack reflects on the history of the churchyard "since the settlement of our island," and gives an outline of the site's role in New York's history-from the Negro Plot to the Great Fire to the Battle of Brooklyn. Of course, the churchyard does not simply remind one of those events; it brings one into tactile interactions with them and creates an embodied experience of New York's and America's cultural origins.

Finally, continuing and expanding on the trope's typical inclusion of the tomb of "My Mother," Jack pays special attention to familial tombstones. He visits the "My Mother" gravestone and thinks its epitaph "sweet" and created from "a most sweet motive." In the context of Jack's orphanhood, this tomb in particular takes on new meaning: the famous tomb inscribed by a loyal, loving son to his mother is visited and remarked upon by an orphan who has no memory of his mother, yet who bears a "sweet motive" to establish a narrative of origins. In his wandering around the churchyard, he also pauses to consider "the tombs of a father and mother, natives of New York, with a numerous family of their children. Haply, the whole of the chain, unbroken, was there" (333). Jack's visitations to tombs of alternatingly national and familial significance blends the two identity crises together. As it had done through its literary trope for decades, Trinity Churchyard immerses the visitor in a space that synthesizes personal identity with national memory. Thus, the experience provides Jack an alternative to his inaccessible familial ancestry: a connection to national origins.

If Jack's quest for personal roots parallels America's yearning for a distinct national identity, then the Trinity Churchyard scene posits a solution for the American nation. While the city's landscape may be ever changing, Trinity Churchyard itself remains inseparably grounded in a local and national past of mythic value. It is the churchyard's urban-pastoral atmosphere and its tangible history - the patriotic inscriptions Jack copies down, the grass nourished from American heroes covering his face-that Jack romantically discovers a meaningful past that forms his current self. For Whitman, as we see in later writings like his Brooklyniana publications and in "The Old Whitman and Van Velsor Cemeteries" in Specimen Days, personal identity is intimately linked as much with familial history as it is with national memory.

After Jack's successful romantic experience in the churchyard, the plot quickly resolves. Covert leaves the country, Jack's friends flourish, and he and Martha-the story's two orphans-marry and form their own family. Having discovered a foundational identity for himself, Jack is able to turn his life forward 
and face modernity with a personal and national foundation to support him. Agent of his own life and at terms with his familial mortality, Jack now is able to assert his own identity.

Finally, it is significant that literature itself is central to Whitman's solution. First, Jack discovers his ancestral identity and saves himself and Martha from the dangers of Covert through the words and textual documentation of Wigglesworth - a character who shares his unique name with an important early American poet. Further, the stimulus for stopping at Trinity Churchyard is Jack's visit to Wigglesworth's tomb. Above the level of characters and plot, it is through a literary trope that Whitman himself provides a solution to his novel's conflict. Thus, while Walt Whitman the New Yorker signals to Trinity Churchyard and its early American roots as a vehicle for establishing a unified national identity, Walt Whitman the newspaperman draws on early and contemporaneous American literature as a powerful tool for community formation.

The trope of Trinity Churchyard engrained the unique New York location as a site of American foundations and identity. For decades before Whitman used it in Fack Engle, both he and others used the trope in isolated yet interconnected periodical texts that themselves were brief moments of pause and contemplation within the busy, chaotic texts of the newspaper page. Whitman did not invent the idea of Trinity Churchyard as a site of national memory, but he was the first to fully integrate it into a longer piece of fiction. When he did so, he drew on the trope's common features and its established meaning to shape his own novel, emphasizing the need of both Jack Engle and Antebellum America to forge a profound connection with the nation's past in order to secure a meaningful identity and a stable future. In these ways, Fack Engle is significant as much in its connection to America's past as it is in its connections to Whitman's own poetic future.

Mellon/ACLS Public Fellow, Library of America scott.t.zukowski@gmail.com 


\section{Notes}

1 Ed Folsom, quoted in Jennifer Schuessler, "In a Walt Whitman Novel, Lost for 165 Years, Clues to 'Leaves of Grass,"' New York Times (February 20, 2017).

2 See Meredith McGill, American Literature and the Culture of Reprinting, 1834-1853 (Philadelphia: University of Pennsylvania Press, 2007); Stephanie M. Blalock, "More Than One Hundred Additional Reprints of Walt Whitman's Short Fiction in Periodicals," Walt Whitman Quarterly Review 35 (Summer 2017), 45-87; Stephanie M. Blalock, "Walt Whitman's Early Fiction in Periodicals: Over 250 Newly Discovered Reprints," Walt Whitman Quarterly Review 30 (Spring 2013), 171-181.

3 Sidney I. Pomerantz, New York An American City 1783-1803: A Study of Urban Life (Port Washington, NY: Ira J. Friedman, Inc., 1965), 230-231.

4 James Miller, Miller's New York As It Is; or Stranger's Guide-Book to the Cities of New York, Brooklyn, and Adjacent Places: Comprising Notices of Every Object of Interest to Strangers; Including Public Buildings, Churches, Hotels, Places of Amusement . . . . (New York: James Miller, 436 Broadway, 1859), 64.

5 Walt Whitman, Life and Adventures of Fack Engle: An Autobiography, ed. Zachary Turpin, Walt Whitman Quarterly Review 34 (Winter/Spring 2017), 262-357 (p. 336). All subsequent references to the novel are from the edition published in the Walt Whitman Quarterly Review.

6 I will be using "graveyard" and "churchyard" interchangeably. Small, local, and often urban "yards" surrounding churches, they are distinguished from the "rural cemetery" (e.g., Greenwood in Brooklyn), which is a large, park-like burial space outside the city limits. See Maria Farland, "Decomposing City: Walt Whitman's New York and the Science of Life and Death," ELH 74 (Winter 2007), 799-827; Paul Outka, “(De)Composing Whitman,” ISLE 12 (Winter 2005), 41-60.; Ann Douglas, The Feminization of American Culture (New York: Alfred A. Knopf, 1977), Chapter 6.

7 “Board of Health.” Poulson's American Daily Advertiser [Philadelphia] (August 1822).

8 Citizen, "To the Mayor, the President, and Members of the Board of Health," New-York American to the Country (January 26, 1822).

9 A Member of Trinity Church, "Trinity Church Yard," Evening Post [New York] (November 11, 1822).

10 “Trinity Church-Yard," American [New York] (February 14, 1833).

11 See Pacific, "New York. June 23, 1852," Alabama Planter [Mobile, AL] (July 3, 1852).

12 Knickerbocker, "To the Evening Post," Evening Post [New York] (January 26, 1833). 
13 "Letters from a Traveller," South Carolina State Gazette and Columbia Advertiser [Columbia, SC] (August 25, 1827).

14 C.L., "For the American," American and Commercial Daily Advertiser [Baltimore, MD] (November 7, 1833).

15 See "Second re-erection of Trinity Church," Nantucket Inquirer [Nantucket, MA] (July 31, 1839) [reprinted from the New-York Sun]; H.A.B. "An hour in Trinity Church Yard," New-York Spectator (November 7, 1839); [Walt Whitman,] "A Brooklynite in N. Y. Church-Yards," Brooklyn Daily Eagle (July 7, 1846); “New York. October 23d, 1850," Boston Daily Evening Transcript (October 25, 1850).

16 See "An Elegant Monument," Sacramento Daily Chronicle [Sacramento, CA] (September 2, 1853, September 9, 1853); "New York Journal," Maine Farmer: An Agricultural fournal and Family Nerwspaper [Augusta, ME] (December 1, 1853); Harriet N. Prewett, "Astor House," Yazoo City Weekly Whig [Yazoo City, MS] (July 28, 1854).

17 [Walt Whitman], "In that cut . ..," Brooklyn Daily Eagle (October 19, 1846).

18 Echoing this sentiment on October 18, 1847, a writer for the Brooklyn Daily Eagle (likely Whitman) wrote that, while the American people were eager to "join in a testimony" to Washington by supporting a proposed monument to him in New York, "to commemorate such a character as Washington we want ... no monument but his country, and his countrymen's hearts! [ . . . ] It is all well enough to raise proud pieces of showy architecture to your Napoleons, your Walter Scotts, or your Wellingtons - the 'great men' of a few ages. But this pure and august being - this man without a flaw-asks no pile of brick, stone, and mortar raised!”

19 [Walt Whitman], "One of the Bold and True," Brooklyn Daily Eagle (November 18, 1846).

20 [Walt Whitman?], "Monument to the Bold and True," Brooklyn Daily Eagle (March 25, 1847).

21 According to William Henry Sutton, a printer's devil for the Eagle during Whitman's tenure there, the editor's daily routine consisted of morning writing followed by a walk, after which he would "return to the office to read proof on the material for the day's paper," suggesting that Whitman was closely attentive to the pieces printed in the Eagle (William Henry Sutton, GF 1: xxi-iii; quoted in Thomas L. Brasher, Whitman as Editor of the Brooklyn Daily Eagle [Detroit: Wayne State UP, 1970], 19).

22 Plantagenet, "For the Easton Gazette. Letter 1," Easton Gazette [Easton, MD] (October 21, 1837).

23 O.P.Q. [Walt Whitman?], "Letter from New York. Scenes and Sights of Broadway," Brooklyn Evening Star (February 20, 1846). I suspect that the author of this letter may have been Whitman himself, who worked at the Brooklyn Evening Star at the time of its publication. In September of the same year, Whitman would publish a short piece entitled, "The Little Sleighers. A Sketch of a Winter Morning on the Battery," echoing this author's attention to "sleighers" of lower Manhattan. See Stephanie M. Blalock, "About 'The Little Sleighers. A Sketch of a Winter Morning on the Battery,"” 
on the Walt Whitman Archive.

24 Philip Hone, August 28, 1839; "For the New-York American," in "Hone Diary," in Hone E Strong Diaries of Old Manhattan, ed. Louis Auchincloss (New York: Abbeville Press, 1989).

25 The term "reflective reverie" is far from perfect, but is meant to varyingly encompass traditionalism, virtue, spirituality, religion, reflection, and, perhaps most of all, reverence for the past and mindfulness of mortality.

26 Richard D. Brown, "Modernization: A Victorian Climax," American Quarterly 27 (1975), 533548 (p. 537-540).

27 Jürgen Heideking, "The Pattern of American Modernity from the Revolution to the Civil War," in Multiple Modernities, ed. Shmuel N. Eisenstadt, (London: Transaction Publishers, 2002), 220.

28 Dorothy Ross, "American Modernities, Past and Present," American Historical Review 116 (June 2011), 702-714 (p. 702).

29 James L. Machor, Pastoral Cities: Urban Ideals and the Symbolic Landscape of America (Madison, WI: University of Wisconsin Press, 1987), 121; David S. Reynolds, Walt Whitman's America: A Cultural Biography (New York: Alfred A. Knopf, 1995), 107.

30 Ellen W. Kramer, "Contemporary Descriptions of New York City and Its Public Architecture ca. 1850," Fournal of the Society of Architectural Historians 27 (1968), 264-280 (p. 270); Edward K. Spann, The New Metropolis: New York City, 1840-1857 (New York: Columbia University Press, 1981), 3.

31 Walt Whitman, "Tear Down and Build Over Again," The American Review: A Whig fournal of Politics, Literature, Art and Science (New York: George H. Colton, 1845), 2:536-538.

32 "For the New-York American," New York American (November 7, 1833).

33 Pacific, "New York. June 23, 1852," Alabama Planter [Mobile, AL] (July 3, 1852).

34 “City Lyrics. A Hymn," New York Herald (May 3, 1846).

35 William E. Huntzicker, The Popular Press, 1833-1865 (Westport, CT: Greenwood Press, 1999), 19-20; Bennett, New York Herald, February 28, 1837, quoted from Huntzicker, 23.

36 Nathaniel P. Willis, “Trinity Churchyard," in Miscellaneous Works of N.P. Willis (New York: J.S. Redfield, Clinton Hall, 1847), 11.

37 Desirée Henderson, “What Is the Grass?": The Roots of Walt Whitman's Cemetery Meditation," Walt Whitman Quarterly Review 25 (Winter 2008), 89-107 (p. 92). 
38 "Letters from a Traveller"; "The Boston Palladium," North Carolina Sentinel [New Bern, SC] (August 29, 1829).

39 See Arion, "An Hour in Trinity Churchyard," Freedom's fournal [New York] (January 25, 1828); "In Trinity church yard," Baltimore Patriot and Mercantile Advertiser [Baltimore, MD] (July 31, 1829); “City Lyrics. A Hymn,” New York Herald (May 3, 1846).

40 James F. Cooper Satanstoe; or The Littlepage Manuscripts. A Tale of the Colony, Volume 1 (New York: Burgess, Stringer \& Co., 1845). Available online at the Early American Fiction Full-Text Database. 99.

41 For more on sites of memory, see Pierre Nova, "Between Memory and History: Les Lieux de Mémoire," Representations 26 (Spring 1989), 7-24.

42 Thomas Bender, "The 'Rural' Cemetery Movement: Urban Travail and the Appeal of Nature," New England Quarterly 47 (June 1974), 196-211 (pp. 196-197).

43 See also Joy M. Giguere, "Localism and Nationalism in the City of the Dead; The Rural Cemetery Movement in the Antebellum South," Fournal of Southern History 84 (2018), 845-882.

44 See Leo Marx, “The Machine in the Garden," New England Quarterly 29 (March 1956), 27-42.

45 My research across every digital database available to me, as well as in microforms and archives, suggests that this is the first time that an account of wandering reflectively for an hour through Trinity Churchyard was printed in a newspaper or other medium. That it is noted as being written "FOR THE FREEDOM'S JOURNAL" indicates that this was not a reprint; however, as Omidsalar et al. articulate in their study of Whitman reprints, database research is imperfect because of limitations in periodical digitization, scholarly access, and OCR technology (Alejandro Omidsalar et al., "Walt Whitman's Poetry Reprints and the Study of Nineteenth-Century Literary Circulation." Walt Whitman Quarterly Review 35 [Summer 2017], 1-44 [pp. 34-35]).

46 Arion, "An Hour in Trinity Churchyard," Freedom's fournal [New York] (January 25, 1828).

47 Juhani Pallasmaa, "Selfhood and the World. Lived Space, Vision and Hapticity," in Senses and the City: An Interdisciplinary Approach to Urban Sensescapes, ed Madalina Diaconu, Eva Heuberger, Ruth Mateus-Berr, Lukas Marcel Vosicky (Berlin: Lit Verlag, 2001), 56.

48 Laura E. Tanner, "Holding On to 9/11: The Shifting Grounds of Materiality," PMLA 127 (January 2012), 58-76.

49 Susan Scheckel, The Insistence of the Indian: Race and Nationalism in Nineteenth-Century American Culture (Princeton, NJ: Princeton University Press, 1998), 7.

50 Publication locations range from Mississippi to Vermont. For five of many examples, see "In Trinity church yard," Baltimore Patriot and Mercantile Advertiser (July 31, 1829); "The Boston 
Palladium," North Carolina Sentinel [New Bern, SC] (August 29, 1829); "In Trinity church yard," Saratoga Sentinel [Saratoga Springs, NY] (October 17, 1829); H.N.P., "Anniversary of the Introduction of Cochituate Water," Boston Daily Evening Transcript (October 25, 1850); Harrient N. Prewett, "Astor House." For publications concentrating on the "My Mother" tombstone in Trinity Churchyard, see the latter three sources above, as well as: "For the New-York American," New York American (February 20, 1833); "For the American," American and Commercial Daily Advertiser [Baltimore, MD] (November 7, 1833); "Memorials to the Dead," Independent Inquirer [Brattleboro, VT] (January 25, 1834); "Memorials to the Dead," Saturday Morning Transcript [Boston, MA] (January 25, 1834); "My Mother," The Sun [Litchfield, CT] (August 27, 1836).

51 It is worth noting that rural cemeteries often restricted visitor access by religion, class, and race, and, located outside the city, they required leisure time, transportation, and sometimes even a visitor's ticket (Henderson 95-96). Trinity, however, was far more democratically accessible as it was located in the heart of lower Manhattan and did not restrict visitors.

52 Samuel Cornish and John Russwurm, “To Our Patrons," Freedom's fournal (March 16, 1827).

53 H.A.E., "An hour in Trinity Church Yard," New-York Spectator (November 7, 1839).

54 Gregory M. Pfitzer, Popular History and the Literary Marketplace, 1840-1920 (Amherst, MA: University of Massachusetts Press, 2008), 23.

55 Kent P. Ljungquist, "Knickerbocker Writers," American History Through Literature 1820-1870, ed. Janet Gabler-Hover and Robert Sattelmeyer (Detroit: Charles Scribner's Sons, 2007), 2:608.

56 Jerome Loving, Walt Whitman: The Song of Himself (Los Angeles: University of California Press, 1999), 90.

57 Jason Stacy, "Washington's Tears: Sentimental Anecdote and Walt Whitman's Battle of Long Island," Walt Whitman Quarterly Review 27 (Spring 2010), 213-226 (p. 214).

58 Later, Whitman would reflect on graveyards (especially those in Brooklyn): "The old graveyards of Brooklyn! What a history is contained in them" ("Brooklyniana X," in Walt Whitman's New York: From Manhattan to Montauk, ed. Henry M. Christman [New York: MacMillan Co., 1963]).

59 In another example of this, the narrator directly asks the reader: "In that distant corner, under that rough pile of ruins, who think you reposes?"

60 For more on Whitman's interaction with these ideas, see Maria Farland, "Decomposing City: Walt Whitman's New York and the Science of Life and Death."

61 "Poem of Wonder at The Resurrection of Wheat," in Leaves of Grass (Brooklyn: Fowler \& Wells, 1856), 202-205. Available on the Walt Whitman Archive.

62 Leaves of Grass, 1855. Available on the Walt Whitman Archive. See Henderson for more on 
62 Leaves of Grass, 1855. Available on the Walt Whitman Archive. See Henderson for more on Whitman's earlier periodical texts related to grass.

63 “Sun-Down Papers.--[No. 6]," Long-Island Democrat (August 11, 1840). Available on the Walt Whitman Archive.

64 "Sun-Down Papers.-[No. 7]," Long-Island Democrat (September 29, 1840). Available on the Walt Whitman Archive.

65 "Letters from a Travelling Bachelor-No. II," New York Sunday Dispatch (October 21, 1849). Available on the Walt Whitman Archive.

66 For more analysis on these texts, see Henderson, "What is Grass?" from page 97 onward.

67 "Greenwood Cemetery," Universalist Union [New York] (November 16, 1839). In The fournalism, vol. I, ed. Herbert Bergman (New York: Peter Lang, 1998), 9-10.

68 "A Visit to Greenwood Cemetery," Sunday Times E Noah's Weekly Messenger [New York] (May 5, 1844). In The fournalism, 1:190-191.

69 Nancy Isenberg and Andrew Burstein, "Introduction," in Mortal Remains: Death in Early America, ed. Nancy Isenberg and Andrew Burstein (Philadelphia: University of Pennsylvania Press, 2003), 7.

70 "Antiquity of Trinity Church Yard," Boston Evening Transcript (July 25, 1846).

71 Charlotte Temple was the fictional tragic heroin in Susanna Rowson's 1790s novel, Charlotte Temple. Trinity Church archivists remain unsure of the tombstone's origins. See "The Mystery of Charlotte Temple," Trinity Church Wall Street blog (December 16, 2008).

72 “The Grave of Charlotte Temple," Spiritual Telegraph [New York] (August 21, 1852).

73 For example, see "A petition," Nantucket Inquirer [Nantucket, MA] (December 2, 1826); "Ward Four,” Boston Evening Transcript (April 12, 1855).

74 The only instance of romantic musings surrounding Christ Church Burial Ground that I have found is from the Easton Gazette, in which the narrator looks out his window at the burial ground and philosophizes on the famous Americans buried there in a manner similar to literature of Trinity Churchyard (Traveller, "A Wet Day at a Window," Easton Gazette [Easton, MD] [June 22, 1839]).

75 “The Poet," in Essays. Second Series (Cambridge: Chadwyck-Healey, 1999), 24.

76 Bonnie Carr O’Neill, “The Personal Public Sphere of Whitman's 1840s Journalism," PMLA 126 (October 2011), 983-998 (p. 995). 
77 Ed Cahill, Liberty of the Imagination: Aesthetic Theory, Literary Form, and Politics in the Early United States (Philadelphia: University of Pennsylvania Press, 2012), 2-4.

78 See "Michael Wigglesworth," Encyclopedia of World Biography 2nd ed, vol. 16 (Farmington Hills, MI: Gale, 2004), 266-267. Gale Virtual Reference Library.

79 See: "Hymn 11," in Pious Songs. Social, Prayer, Closet, and Camp Meeting Hymns, and Choruses. Third Edition, Enlarged and Improved (Baltimore: Armstrong \& Berry, 1836), 12-13; "Hymn 22," in The Camp-meeting Chorister, Or, A Collection of Hymns and Spiritual Songs . . . (Philadelphia: J. Clarke, 1830), 23-24; "Calvary," The Christian's Spiritual Song Book . . ., ed. John Stamp (London: W. Brittain, 1845), 84 .

80 For a manuscript that may have served as Whitman's worksheet for modifying the song, see "A Soul Duet" in the Walt Whitman Archive.

81 Fack Engle, 332. Zachary Turpin, quoted in Schuessler. 